\title{
ПОРІВНЯЛЬНА ОЦІНКА ТЕЛИЦЬ УКРАЇНСЬКОЇ ЧОРНО-РЯБОЇ ТА ЧЕРВОНО-РЯБОЇ МОЛОЧНИХ ПОРІД ЗА РОСТОМ, ПРОМІРАМИ ТА ПРИРОСТАМИ ЖИВОЇ МАСИ НА ЧЕРНІГІВЩИНІ
}

\author{
Рубцов Ігор Олександрович \\ кандидат сільськогосподарських наук, доцент \\ Сумський національний аграрний університет \\ ORCID 0000-0002-7591-5905 \\ E-mail: rubtsov_igor68@ukr.net
}

Стан вирощування ремонтного молодняку великої рогатої худоби молочного напряму продуктивності завжди цікавив фрахівиів тваринницької галузі. Це в першу чергу було пов'язане з тим, що при оптимальних умовах формується фенотип тварин, який наближується до генетичного потенціалу молочної продуктивності. В умовах сучасних відносин на рину це має велике значення для одержання продукції високої якості з мінімальними витратами і меншою собівартістю. Тому метою статті було дослідити у порівнянні особливості росту тварин двох основних порід, які розводяться 8 Україні, а також встановити особливості формування екстер'єру та молочного типу у ремонтних телиць в різні вікові періоди. Дослідження проводились в умовах ПОСП (приватне орендне сільськогосподарське підприємство) «Хлібороб» Ічнянського району Чернігівської області. Був зроблений порівняльний аналіз стану вирощування ремонтного молодняку української чорно-рябої та червоно-рябої молочних порід, шляхом аналізу живої маси від народження до 18 місяців, та взяттям основних промірів з подальшим розрахунком індексів будови тіла. Суттєвої різниці між тваринами обох порід за показниками росту не виявлено. Так при народженні і в 3 місяиі різниця взагалі була відсутня. У 6 місяців вона склала 3,1 ке на користь телиць української червоно-рябої молочної породи, а у віці 6 місяців ми спостерігали деяке перевищення вже тварин української чорно-рябої молочної породи на 3,3 ке. Це перевищення просліджувалось у подальшому, і вже у 18 місяців становило 8,1 ке, але як і у попередніх періодах воно було невірогідне. Добові прирости за цей період складали від народження до 3 - х місяців 779,4 та 778,3 г., відповідно по українській чорно-рябій молочні та українській червоно-рябій молочній, від 3 до 6 місяців 818,6 та 853,1 2, від народження до 6 місяців 799,0 та 815,7 2, від 6 до 12 місяців 807,3 та 771,9 2, від народження до 9, 12 та до 18 місяиів 808,8 і 801,1 та 792,1 і 782,9 г та 751,9 і 736,9 г. У всі вікові періоди вірогідної різниці між породами не виявлено. Коефріцієнт повторюваності живої маси при народженні з живою масою в 3 місяиі у тварин української чорно-рябої молочної складав + 0,138, у 6 місяців + 0,134, у 12 місяців + 0,104, у 18 місяиів + 0,105. При цьому в перших двох періодах він був вірогідний $(P>0,95)$, то за останні періоди невірогідним. Показники промірів та індексів будови тіла також вказували на те, що тварини обох порід добре розвинені, мають чітко виражений ухил в бік формування тварин молочного типу.

Ключові слова: українська чорно-ряба молочна, українська червоно-ряба молочна, проміри, індекси, екстер'єр

DOI: https://doi.org/10.32845/bsnau.Ivst.2021.1.11

Створення високопродуктивного молочного стада в значній мірі залежить від системи і технологічних особливостей вирощування ремонтного молодняку. Інтенсивність росту тварин в значній мірі визначає його живу масу у дорослому вигляді, а також розвиток основних органів, від формування яких залежить майбутня жива маса. Вона у свою чергу впливає на прояв генетичного потенціалу молочної продуктивність $[1,3,5]$.

У кожному господарстві існує специфічна система вирощування ремонтного молодняку, яка притаманна лише даному господарству. Це пов'язано в першу чергу з особливостями утримання та вирощування в різні вікові періоди і годівлею молодняку від народження і до моменту запліднення та отелення.

Процес росту і розвитку ремонтного молодняку протягом всього періоду вирощування обумовлюється впливом дії багатьох факторів, як генотипового походження так і факторів зовнішнього середовища [2, 4].

Вік першого осіменіння залежить в першу чергу від приростів живої маси в різні вікові періоди. У більшості господарств значні проблеми при вирощуванні виникають після закінчення молочного періоду, що дуже складно надолужити у наступні періоди. Кожен місяць затримки в осіменінні призводить до збільшення собівартості вирощування нетелі на 5-7 \%. Це в свою чергу суттєво впливає на ефеективність ведення галузі молочного скотарстві і собівартість отрима-

ного молока. Тому останнім часом в більшості господарств 3 розвиненим молочним скотарством просліджується чітка тенденція проведення першого осіменіння як можна раніше при досягненні живої маси 360 кг у віці 14-15 місяців і отримання від таких тварин додаткових прибутків від 15 до 25\% $[6,8,12]$.

Таким чином питання росту і розвитку тварин мають велике значення при формуванні молочного типу і продуктивності, так як вони тісно пов'язані між собою. Оцінка тварин за зовнішнім виглядом простий, але достатньо ефективний метод оцінки господарсько-корисних ознак молочної худоби. Це в першу чергу пов'язано з переводом галузі на сучасні промислові технології. Тільки тварини з міцною конституцією і певними показниками екстер'єру можуть володіти кріпким здоров'ям, здатним протягом достатньо тривалого часу володіти високою продуктивністю, відтворювальними властивостями і тривалим продуктивним довголіттям $[7,9,10]$.

Оцінка екстер'єру корів за промірами у селекційноплемінній роботі має важливе значення, оскільки завдяки ій можна отримати об'єктивний цифровий вираз розвитку найважливіших частин тіла тварини у будь-який період іï життя, провести порівняльний аналіз як у межах окремих тварин, так і різних селекційних груп, стад, ліній та внутрішньопородних типів. Основні методи морфологічних досліджень росту тварин передбачають облік живої маси та лі- 
нійних розмірів $[9,11]$.

Виходячи $з$ вищенаведеного метою статті було дослідити у порівнянні особливості росту тварин двох основних порід, які розводяться в Україні в умовах одного господарства, а також встановити особливості формування молочного типу у ремонтних телиць в різні вікові періоди.

Матеріали і методи досліджень. Дослідження проводились у ПОСП (приватне орендне сільськогосподарське підприємство) «Хдібороб» Ічнянського району Чернігівської області. При загально високому зоотехнічному рівні. Так продуктивність за 2020 рік склала понад 8856 кг на фуражну корову і добовими приростами в межах 750 г. Об'єктом досліджень були ремонтні телички української чорно-рябої та червоно-рябої молочних порід (2017-2018 років народження).

Вивчення особливостей росту і екстер'єру проводили класичними зоотехнічними методиками шляхом контрольних зважувань в різні вікові періоди від народження до 18 місяців і взяття промірів (за Е.Я. Борисенко 1966, Н.А. Кравченко 1963) з подальшим розрахунком добових та відносних приростів, взяття промірів та розрахунком індексів будови тіла.

Біометричну обробку результатів проводили за загальноприйнятою методикою (Плохинського М.О., 1969 р.),

Результати досліджень. Відомо, що ріст та розвиток тісно пов'язані між собою і в різні вікові періоди окремі органи і тканини мають неоднакові показники напруженості росту. В першу чергу страждають ті, які в цей період повинні більш інтенсивно розвиватись. Тому одним із головних завдань вирощування ремонтного молодняку - це забезпечення постійно стабільного рівня, при якому тварини в найкоро- тші терміни могли досягнути фізіологічної зрілості.

Динаміка зміни живої маси у ремонтних телиць української чорно-рябої та червоно-рябої молочної представлена у таблиці 1. Отримані дані свідчать, що показники живої маси в різні вікові періоди у дослідних тварин відповідали стандартам згідно (Інструкції бонітування великої рогатої худоби молочних і молочно-м'ясних порід, 2003р.). За всіма врахованими періодами ми спостерігали перевищення живої маси над стандартами породи. Так у віці 6 місяців воно склало 7,8 та 5,9 кг, у 12 місяців 39,2 та 31,9 кг і у 18 місяців 60,6 та 47,0 кг, відповідно у тварин української чорно-рябої та червоно-рябої молочних порід. Наведені показники свідчать про те, що в господарстві дуже серйозне ставлення до умов вирощування ремонтного молодняку. Але також слід відмітити, що стандарти, які на сьогодні існують не в повній мірі відповідають сучасним вимогам.

Суттєвої різниці між тваринами обох порід за показниками росту не виявлено. Так при народженні і в 3 місяці різниця взагалі була відсутня. У 6 місяців вона склала 3,1 кг на користь телиць української червоно-рябої молочної породи. У віці 6 місяців ми спостерігали деяке перевищення вже тварин української чорно-рябої молочної породи на 3,3 кг. Воно просліджувалось і у подальшому, і вже у 18 місяців становило 8,1 кг, але як і попередніх періодах воно було невірогідне.

Коефріцієнт мінливості у дослідних тварин знаходився в межах від 11,3 \% до 18,1 \% по українській чорно-рябій молочній і від 11,6 до 13,7 \% по українській червоно-рябій молочній. Найнижча спостерігалась у тварин при народженні, а найбільша в 6 місяців по обох групах.

Таблиця 1

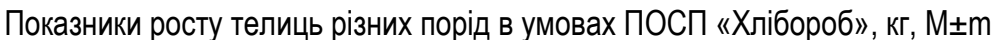

\begin{tabular}{|l|c|c|c|c|c|c|c|}
\hline \multicolumn{1}{|c|}{ Порода } & \multirow{2}{*}{$\mathrm{n}$} & \multicolumn{6}{c|}{ Bік, міс } \\
\cline { 3 - 8 } & при народжені & 3 міс. & 6 міс. & 9 міс & 12 міс. & 18 міс. \\
\hline $\begin{array}{l}\text { Українська чорно- } \\
\text { ряба молочна }\end{array}$ & 213 & $34,1 \pm 0,25$ & $104,2 \pm 0,88$ & $177,8 \pm 1,50$ & $252,5 \pm 1,8$ & $323,2 \pm 2,56$ & $440,1 \pm 3,23$ \\
\hline Cv, \% & & 11,3 & 13,2 & 18,1 & 13,2 & 12,3 & 15,2 \\
\hline $\begin{array}{l}\text { Українська червоно- } \\
\text { ряба молочна }\end{array}$ & 126 & $34,1 \pm 0,32$ & $104,1 \pm 1,07$ & $180,9 \pm 1,90$ & $250,4 \pm 2,1$ & $319,9 \pm 3,24$ & $432,0 \pm 5,26$ \\
\hline Cv, & & 11,6 & 12,9 & 13,7 & 12,5 & 12,7 & 11,9 \\
\hline
\end{tabular}

Найбільш інтенсивним ростом характеризувалися тварини в перші вікові періоди від народження до 12 місяців. Добові прирости за цей період складали від народження до 3 - х місяців 779,4 та 778,3 г., відповідно по українській чорно-рябій та українській червоно-рябій молочній, від 3 до 6 місяців 818,6 та 853,1 г, від народження до 6 місяців 799,0 та 815,7 г, від 6 до 12 місяців 807,3 та 771,9 г, від народження до 9, 12 та до 18 місяців 808,8 і 801,1 та 792,1 і 782,9 г та 751,9 і 736,9 г. У всі вікові періоди вірогідної різниці між породами не виявлено.

Особливості росту ремонтних телиць забезпечили відносний приріст живої маси від народження до 3 - х місяців 100,6 та 101,3 \%, відповідно по українській чорно-рябій та червоно-рябій молочній, від 3 до 6 місяців - 49,9 та 53,9 \% від 6 до 12 місяців - 62,1 та 55,5\%, від народження до 6 місяців - 135,5 та 136,6 \%, від народження 9 місяців 152,2 та 152,0 \% від народження до 12 місяців - 161,8 та 161,5 \%, від народження до 18 місяців - 171,2 та 170,7\%.

Слід сказати, що ріст тварин обох порід був достатньо динамічним, відповідав сучасним вимогам для одер- жання дорослих тварин 3 живою масою 650 - 700 кг.

Жива маса при народженні мала незначний вплив на показники росту телиць в інші вікові періоди, але між породами були суттєві розбіжності. Так коефріцієнт повторюваності живої маси при народженні 3 живою масою в 3 місяці у тварин української чорно-рябої молочної складав + 0,138, у 6 місяців + 0,134, у 12 місяців + 0,104, у 18 місяців $+0,105 \pm$. При цьому в перших двох періодах він був вірогідний (P> 0.95), то за останні періоди невірогідним. Найбільший коефіцієнт спостерігався за період від 3 до 6 місяців + 0,470 (P> 0.999), та від 6 до 12 місяців + 0,288 ( $\mathrm{P}>0.999)$.

Взаємозв'язок живої маси в різні періоди у тварин української червоно-рябої молочної породи був дещо вищим і у всі періоди вірогідним. Так від народження до 3 місяців + 0,284 ( $P>0.99)$, до 6 місяців + 0,190 ( $P>0.95)$, до 12 місяців $+0,203$ ( $P>0.99)$, до 18 місяців $+0,198$ ( $P>0.95)$. Як і у попередній групі найбільший коефіцієнт повторюваності за період від 3 до 6 місяців + 0,511 (Р> 0.999), та від 6 до 12 місяців $+0,287(P>0.99)$ 
Таблиця 2

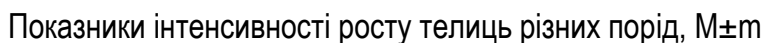

\begin{tabular}{|c|c|c|c|c|c|c|c|c|c|}
\hline \multirow[b]{3}{*}{$\begin{array}{c}\text { Показники, } \\
\text { вік }\end{array}$} & \multicolumn{6}{|c|}{ Порода } & \multirow{2}{*}{\multicolumn{3}{|c|}{ \pm УЧРМ до УЧеРМ }} \\
\hline & \multicolumn{3}{|c|}{ УЧРМ, $n=213$} & \multicolumn{3}{|c|}{ УЧеРM. N = 126} & & & \\
\hline & $\begin{array}{l}\text { добовий } \\
\text { приріст, г }\end{array}$ & $\begin{array}{l}\text { відносний, } \\
\text { приріст, \% }\end{array}$ & $\begin{array}{c}\text { коефріцієнт } \\
\text { повторюваності, } \\
r \pm m_{\mathrm{r}}\end{array}$ & $\begin{array}{l}\text { добовий } \\
\text { приріст, г }\end{array}$ & $\begin{array}{l}\text { відносний, } \\
\text { приріст, \% }\end{array}$ & 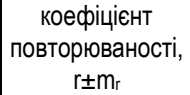 & $\begin{array}{l}\text { добовий } \\
\text { приріст, г }\end{array}$ & $\begin{array}{l}\text { відносний, } \\
\text { приріст, \% }\end{array}$ & $\begin{array}{c}\text { коефріцієнт } \\
\text { повторюваності }\end{array}$ \\
\hline $0-3$ & $779.4 \pm 9.8$ & $100,6 \pm 1,7$ & $0.138 \pm 0,067$ & $778.3 \pm 11.4$ & $101,3 \pm 2,1$ & $0.284 \pm 0,082$ & +1.1 & +0.4 & -0.146 \\
\hline $3-6$ & $818.6 \pm 14.8$ & $49.9 \pm 1.1$ & $0.470 \pm 0,053$ & $853.1 \pm 19.0$ & $53,9 \pm 1.3$ & $0.511 \pm 0,066$ & -34.5 & +0.2 & -0.041 \\
\hline $0-6$ & $799.0 \pm 8.2$ & $135,5 \pm 2.1$ & $0.134 \pm 0,067$ & $815.7 \pm 10.9$ & $136,6 \pm 2,5$ & $0.190 \pm 0,086$ & -16.7 & -9.2 & -0.056 \\
\hline $0-9$ & $808,8 \pm 10,1$ & $152,2 \pm 2,4$ & $0,128 \pm 0,064$ & $801,1 \pm 12,7$ & $152,0 \pm 2,8$ & $0,196 \pm 0,088$ & $-7,7$ & $-0,2$ & $-0,092$ \\
\hline $6-12$ & $807.3 \pm 15.1$ & $62.1 \pm 1.4$ & $0.288 \pm 0,062$ & $771.9 \pm 18.2$ & $55,5 \pm 1,8$ & $0.287 \pm 0,082$ & +35.4 & +5 & +0.001 \\
\hline $0-12$ & $792.1 \pm 7.0$ & $161,8 \pm 2.3$ & $0.104 \pm 0,067$ & $782.9 \pm 8.8$ & $161,5 \pm 2,6$ & $0.203 \pm 0,085$ & +9.2 & +11 & -0.099 \\
\hline $0-18$ & $751,9 \pm 6,8$ & $171,2 \pm 2,4$ & $0,105 \pm 0,068$ & $736,9 \pm 8,0$ & $170,7 \pm 2,9$ & $0,198 \pm 0,086$ & $+15,0$ & $+23,7$ & $-0,093$ \\
\hline
\end{tabular}

Про генетичні можливості розвитку екстер'єру тварин української чорно-рябої та червоно-рябої молочних порід достатньою мірою вказують показники промірів оцінених телиць в різні вікові періоди від народження до 18 місяців (таблиця 3).

За висотою в холці - ознаку, яка характеризує загальний розвиток тулуба тварин можна віднести до добре розвинених в усі вікові періоди. Показники даного проміру вказують на те, що більш інтенсивний ріст відбувався в перші періоди життя, а далі дещо сповільнювався. Так у телиць української чорно-рябої молочної породи з 3 до 6 місяців промір збільшився на 12,1 см 36 до 9 місяців на 11,0 кг а з 9 до 12 місяців на 3,0 см, а з 12 до 18 місяців на 5,5 см. Тобто за останні 9 місяців в середньому ріст збільшувався в середньому в межах 1,0 см за місяць.

Подібна ситуація просліджується і у телиць української червоно-рябої молочної породи. Так з 3 до 6 місяців висота збільшилась на 11,7 см, з 6 до 9 місяців на 10,2 см, то 39 до 12 місяців на 3,4 см і з 12 до 18 місяців на 5.0 см.

За глибиною грудей збільшення у тварин української чорно-рябої молочної породи від 3 до 6 місяців на 12,4 кг (29,3 \%), з 6 до 9 місяців - 5,8 см (10,6 \%), з 9 до 12 місяців 4,1 см (6,8 \%) і з 12 до 18 місяців 4,3 см (6,7\%). По червонорябій ці показники становили 12,4 кг (28,9 \%), 4,6 см (8,3 \%), 5,3 см (8,8 \%) та 3,8 см (5,8 \%).

Найбільш інтенсивно тварини розвивались в ширину, на що вказують проміри ширина грудей та ширина в маклаках. Так ширина грудей з 3 до 18 місяців збільшилась на 20,8 см (97,6%), ширина в маклаках на 21,1 см (91,7\%) по українській чорно-рябій молочній і на 20,3 см (94,4\%) та 20,7 см (88,8 \%) по українській червоно-рябій молочній. За періодами це становило з 3 до 6 місяців 11,0 та 9,8 см, з 6 до 9 місяців 3,5 та 3,5 см, з 9 до 12 місяців 3,5 та 4,2 см і 3 12 до 18 місяців 2,8 та 3,6 см по українській чорно-рябій молочній і 10,7 та 9,7 см і 4,0 та 4,2 см і 2,8 та 3,0 см і 2,9 та 3,8 см, відповідно.

Проміжне значення за інтенсивністю розвитку між висотними і широтними промірами займають довжина тулуба і обхват грудей. Саме від їх розвитку в першу чергу залежить жива маса тварини. Так навскісна довжина тулуба збільшилась з 97,6 см у 3-х місячному віці до 146,2 см у 18 місяців, що становить 48,6 см (49,8\%) і обхват грудей 3 110,6 до 182,1 см - 71,5 см (64,6 \%) по українській чорнорябій молочній і з 97,0 до 145,8 см - 48,8 см (50,3 \%) навскісна довжина тулуба і з 111,4 до 181,1 см - 69,7 см (62,5 \%), відповідно по українській червоно-рябій молочній. По періодам це становило за довжиною від 3 до 6 місяців 17,7 см, від 6 до 9 - 6,2 см, від 9 до 12 - 7,6 см і від 12 до 18 - 17,1 см, за обхватом - 20,4, 14,3, 9,7 і 27,1 см, по українській чорно-рябій молочній і 18,4, 6,3, 7,8 та 16,3 см за довжиною і $21,7,11,6,10,8$ та 25,6 см, відповідно по українській червоно-рябій молочній.

Вивчення окремих промірів тіла не дає повної можливості оцінити загальний гармонійний розвиток, тому нами були розраховані основні індекси будови тіла (таблиця 4). Були вивчені шість індексів будови тіла. Вони дають певне уявлення про пропорційність розвитку окремих статей, дозволяють встановити морфологічні особливості формування типу тварин в онтогенезі, інтенсивно використовуються для оцінці тварин в загальній структурі селекційноплемінної роботи з молочною худобою.

Формування типу будови тіла телиць різних молочних порід, $\mathrm{M \pm m}$

Таблиця 3

\begin{tabular}{|c|c|c|c|c|c|c|c|c|}
\hline $\begin{array}{c}\text { Показники, } \\
\text { вік, міс }\end{array}$ & \multirow{2}{*}{$\mathrm{n}$} & \multicolumn{7}{|c|}{ Проміри тіла, см } \\
\cline { 2 - 8 } & висота в холці & глибина грудей & ширина грудей & ширина в маклаках & навскісна довжина тулуба & обхват грудей & обхват п'ястка \\
\hline 3 & 213 & $97,9 \pm 0,4$ & $42,3 \pm 0,2$ & $21,3 \pm 0,1$ & $23,0 \pm 0,1$ & $97,6 \pm 0,2$ & $110,6 \pm 0,4$ & $11,13 \pm 0,11$ \\
\hline 6 & 213 & $110,0 \pm 0,4$ & $54,7 \pm 0,2$ & $32,3 \pm 0,2$ & $32,8 \pm 0,2$ & $115,3 \pm 0,3$ & $131,0 \pm 0,4$ & $13,57 \pm 0,07$ \\
\hline 9 & 213 & $121,0 \pm 0,2$ & $60,5 \pm 0,2$ & $35,8 \pm 0,1$ & $36,3 \pm 0,1$ & $121,5 \pm 0,2$ & $145,3 \pm 0,4$ & $16,03 \pm 0,07$ \\
\hline 12 & 213 & $124,0 \pm 0,2$ & $64,6 \pm 0,2$ & $39,3 \pm 0,2$ & $40,5 \pm 0,2$ & $129,1 \pm 0,2$ & $155,0 \pm 0,4$ & $17,60 \pm 0,08$ \\
\hline 18 & 213 & $129,5 \pm 0,2$ & $68,9 \pm 0,2$ & $42,1 \pm 0,2$ & $44,1 \pm 0,2$ & $146,2 \pm 0,2$ & $182,1 \pm 0,4$ & $18,11 \pm 0,08$ \\
\hline \multicolumn{7}{|c|}{ українська червоно-ряба молочна, $\mathrm{n}=126$} \\
\hline 3 & 126 & $98,8 \pm 0,5$ & $42,9 \pm 0,3$ & $21,5 \pm 0,2$ & $23,3 \pm 0,2$ & $97,0 \pm 0,2$ & $111,4 \pm 0,5$ & $11,90 \pm 0,13$ \\
\hline 6 & 126 & $110,5 \pm 0,4$ & $55,3 \pm 0,3$ & $32,2 \pm 0,3$ & $33,0 \pm 0,2$ & $115,4 \pm 0,5$ & $133,1 \pm 0,5$ & $13,60 \pm 0,08$ \\
\hline 9 & 126 & $120,7 \pm 0,3$ & $59,9 \pm 0,3$ & $36,1 \pm 0,2$ & $37,2 \pm 0,2$ & $121,7 \pm 0,3$ & $144,7 \pm 0,2$ & $16,02 \pm 0,09$ \\
\hline 12 & 126 & $124,1 \pm 0,2$ & $65,2 \pm 0,3$ & $38,9 \pm 0,2$ & $40,2 \pm 0,3$ & $129,5 \pm 0,2$ & $155,5 \pm 0,5$ & $17,72 \pm 0,10$ \\
\hline 18 & 126 & $129,1 \pm 0,2$ & $69,0 \pm 0,3$ & $41,8 \pm 0,2$ & $44,0 \pm 0,3$ & $145,8 \pm 0,2$ & $181,1 \pm 0,5$ & $18,09 \pm 0,10$ \\
\hline
\end{tabular}


Таблиця 4

Індекси будови тіла телиць різних молочних порід, $\mathrm{M} \pm \mathrm{m}$

\begin{tabular}{|c|c|c|c|c|c|c|c|}
\hline $\begin{array}{c}\text { Показники, вік, } \\
\text { міс }\end{array}$ & \multirow{2}{*}{$\mathrm{n}$} & \multicolumn{9}{|c|}{ Індекси, \% } \\
\cline { 3 - 8 } & довгоногості & розтягнутості & грудний & збитості & \multicolumn{1}{c|}{ костистості } & тазо-грудний \\
\hline \multicolumn{7}{|c|}{ українська чорно-ряба молочна, } \\
\hline 3 & 213 & $56,5 \pm 0,1$ & $99,7 \pm 0,4$ & $50,3 \pm 0,2$ & $113,7 \pm 0,4$ & $11,39 \pm 0,11$ & $92,7 \pm 0,5$ \\
\hline 6 & 213 & $50,2 \pm 0,2$ & $104,8 \pm 0,4$ & $59,2 \pm 0,4$ & $113,0 \pm 0,4$ & $12,37 \pm 0,07$ & $98,5 \pm 0,7$ \\
\hline 9 & 213 & $50,0 \pm 0,2$ & $100,5 \pm 0,2$ & $59,0 \pm 0,3$ & $119,2 \pm 0,4$ & $13,25 \pm 0,06$ & $98,8 \pm 0,4$ \\
\hline 12 & 213 & $48,0 \pm 0,2$ & $104,1 \pm 0,2$ & $61,1 \pm 0,3$ & $119,9 \pm 0,3$ & $14,19 \pm 0,06$ & $97,1 \pm 0,5$ \\
\hline 18 & 213 & $46,8 \pm 0,2$ & $112,9 \pm 0,2$ & $61,1 \pm 0,3$ & $124,6 \pm 0,3$ & $13,98 \pm 0,06$ & $95,5 \pm 0,4$ \\
\hline \multicolumn{7}{|c|}{ українська червоно-ряба молочна } \\
\hline 3 & 126 & $56,3 \pm 0,1$ & $98,8 \pm 0,5$ & $50,2 \pm 0,3$ & $115,2 \pm 0,5$ & $12,06 \pm 0,12$ & $92,4 \pm 0,7$ \\
\hline 6 & 126 & $49,8 \pm 0,3$ & $104,3 \pm 0,5$ & $58,3 \pm 0,5$ & $115,0 \pm 0,5$ & $12,34 \pm 0,08$ & $97,7 \pm 0,9$ \\
\hline 9 & 126 & $50,3 \pm 0,2$ & $101,0 \pm 0,3$ & $60,0 \pm 0,4$ & $119,3 \pm 0,5$ & $13,29 \pm 0,08$ & $97,3 \pm 0,5$ \\
\hline 12 & 126 & $47,5 \pm 0,2$ & $104,3 \pm 0,2$ & $59,8 \pm 0,4$ & $120,9 \pm 0,4$ & $14,28 \pm 0,08$ & $96,8 \pm 0,7$ \\
\hline 18 & 126 & $46,6 \pm 0,2$ & $112,9 \pm 0,2$ & $60,6 \pm 0,3$ & $124,2 \pm 0,4$ & $14,01 \pm 0,07$ & $95,0 \pm 0,6$ \\
\hline
\end{tabular}

Відомо, що в ембріональний період у худоби більш інтенсивно розвиваються кінцівки, а в постембріональний осьовий скелет, тому при нормальному розвитку телиць 3 віком індекс довгоногості повинен зменшуватись. Це чітко просліджується по обох породах, з 56,5 до 46,8 \% та з 56,3 до 46,6 \% відповідно по українській чорно-рябій та червонорябій молочній породі. Така величина індексу найбільш притаманна молочній худобі і у подальшому до завершення росту тварини вона повинна ще зменшитись.

Співвідношення довжини тулуба до висоти у холці визначає індекс розтягнутості, який з віком у телиць збільшувавсяся 3 98,8 до 112,9 \%. Це ще раз підтверджує, що після народження тварини більш інтенсивно розвиваються у довжину ніж у висоту.

Тазо-грудний індекс вказує на співвідношення ширини грудей до маклаків. Найбільший показник цього індексу просліджувався у телиць в 6 та 9 місяців, але у подальшому при формуванні молочної корови він повинен зменшуватись.

Грудний індекс був найменший у телиць в 3 місяці, у подальші вікові періоди він знаходився практично на одному рівні.
Індекс збитості $€$ показником добре розвинутої тварини, оскільки він вираховується за співвідношенням обхвату грудей до навскісної довжини тулуба. У наших дослідженнях цей індекс дещо відрізняється віковою мінливістю, з віком він збільшувався, але його стан свідчить про хороші показники розвитку телиць у всі вікові періоди по обох породам.

Висновки. Ріст та розвиток ремонтних телиць обох порід був достатньо динамічним, він відповідає сучасним вимогам за інтенсивністю вирощування та добовими приростами.

Між значеннями живої маси в різні вікові періоди існують не високі позитивні достовірні кореляційні зв'язки. Вони вищі у телиць української червоно-рябої молочної породи

Рівень розвитку промірів і індексів будови тіла ремонтних телиць української чорно-рябої та червоно-рябої молочної породи в різні вікові періоди свідчать, що в процесі росту просліджується позитивна динаміка формування екстер'єру тварин в напрямку молочного типу.

\section{Список використаної літератури:}

1. Зубець М. В., Сірацький Й. З., Данилків Я. Н. Вирощування ремонтних телиць. К.: Урожай, 1993. 136 с.

2. Ивашков А. И., Рыжкова Л. Ю. Особенности роста высокопродуктивных коров. Вестник Российского государственного аграрного заочного университета. 2006. № 1. (6), С. 121-122.

3. Кузів М. І. Ваговий та лінійний ріст телиць української чорно-рябої молочної породи в умовах західного регіону України. Вісник Сумського національного аграрного університету. 2013. №1, С. 40-43.

4. Ладика В. І., Хмельничий С. Л. Оцінка росту ремонтних телиць Сумського внутрішньопородного типу української чорно-рябої молочної породи за промірами та приростами живої маси у віковій динаміці. Сумського НАУ. Серія «Тваринництво». - Вип. 5/1 (31). - 2017. - С. 3-8.

5. Литвиненко Т. В. Вікові зміни інтенсивності росту ремонтних телиць голштинської породи. Вісник Сумського НАУ. Серія Тваринництво. Суми. 2010. Вип. № 12 (18). С. 73-75.

6. Маньковський А. Я. Молочна продуктивність первісток залежно від живої маси телиць та віку отелення. Науковий вісник національного університету біоресурсів і природокористування України. 2009. Вип. 138, С. 63-68.

7. Підпала Т. В., Ясевін С. Є., Дровняк О. В. Інтенсивне вирощування ремонтного молодняку молочної худоби. Сучасні проблеми селекиії, розведення та гігієни тварин. Збірник наукових праць ВНАУ. 2011. № 11 (51), С.117-120.

8. Скляренко Ю. И. Влияние интенсивности развития телочек на их дальнейшие хозяйственно-полезные признаки. Научно-технический бюллетень Института животноводства Национальной академии аграрных наук Украины. 2018. №119, С. 134-141.

9. Хмельничий Л. М. Оцінка росту і розвитку телиць української червоно-рябої молочної породи при використанні вагових та лінійних параметрів. Вісник Сумського НАУ. Серія «Тваринництво». Вип. 12 (21). 2012. С. 18-21.

10. Хмельничий Л. М., Лобода В. П. Характеристика ремонтних телиць української червоно-рябої молочної породи за розвитком живої маси. Вісник Сумського НАУ. Серія «Тваринництво». Вип. 2/2 (25). 2014. С. 3-6.

11. Хмельничий Л. М. Оцінка екстер'єру тварин в системі селекції великої рогатої худоби: дис. доктора сільськогоспо- 
дарських наук : $06.02 .01 / /$ Л. М. Хмельничий. с. Чубинське, 2005. 430 с.

12. Чернявська Т. О., Скляренко Ю. І., Іванкова І. П. Вплив темпів розвитку ремонтних телиць Сумського внутрішньопородного типу української чорно-рябої молочної породи на молочну продуктивність корів первісток. Вісник Сумського НАУ. Серія «Тваринництво». Вип. 7 (33). 2017. С. 150-153.

\section{References:}

1. Zubets, M.V., Siratskyi, Y.Z. and Danylkiv, Ya.N., 1993. Vyroshchuvannia remontnykh telyts [Growing of repair heifers], K.: Urozhai, pp. 136.

2. Ivashkov, A.I. and Ryzhkova, L.Yu., 2006. Osobennosti rosta vysokoproduktivnykh korov. Vestnik Rossiyskogo gosudarstvennogo agrarnogo zaochnogo universiteta [Features of the growth of highly productive cows]. Vestnik Rossiyskogo gosudarstvennogo agrarnogo zaochnogo universiteta, issue 1(6), pp. 121-122.

3. Kuziv, M.I., 2013. Vahovyi ta liniinyi rist telyts ukrainskoi chorno-riaboi molochnoi porody v umovakh zakhidnoho rehionu Ukrainy [Weight and linear growth heifers Ukrainian black-and-white dairy cattle in the western region of Ukraine]. Visnyk Sumskoho natsionalnoho ahrarnoho universytetu, issue 1, pp. 40-43.

4. Ladyka V.I., Khmelnychyy S.L. 2017 Otsinka rostu remontnykh telyts Sumskoho vnutrishnoporodnoho typu ukrayinskoyi chorno-ryaboyi molochnoyi porody za promiramy ta pryrostamy zhyvoyi masy u vikoviy dynamitsi - Estimation of growth of repair heifers of Sumy intrabreed type of Ukrainian black-spotted dairy breed by measurements and increments of live mass in age dynamics Visnyk Sums'koho NAU. Seriya Tvarynnytstvo - Bulletin of Sumy National Agrarian University, series of Animal Husbandry. 5/1 (11): 3-8.

5. Lytvynenko, T. V. 2010. Vikovi zminy intensyvnosti rostu remontnykh telyts' holshtyns'koyi porody - Age changes of repair heifers growth intensity of the Holstein breed. Visnyk Sums'koho NAU. Seriya - Tvarynnytstvoll. Sumy - Bulletin of Sumy National Agrarian University, series of Animal Husbandry. Sumy, 12(18):73-75.

6. Mankovskyi, A. la., 2009. Molochna produktyvnist pervistok zalezhno vid zhyvoi masy telyts ta viku otelennia [Firstborn dairy productivity depending on the live weight of calves and calving age]. Naukovyi visnyk natsionalnoho universytetu bioresursiv $i$ pryrodokorystuvannia Ukrainy, issue 138, pp. 63-68.

7. Pidpala, T.V., Yasevin, S. le. and Drovniak, O. V., 2011. Intensyvne vyroshchuvannia remontnoho molodniaku molochnoi khudoby. Suchasni problemy selektsii, rozvedennia ta hihiieny tvaryn [Intensive cultivation of dairy cattle repair young. Modern problems of selection, breeding and hygiene of animals]. Suchasni problemy selektsii, rozvedennia ta hihiieny tvaryn. Zbirnyk naukovykh prats VNAU, issue 11(51), pp.117-120.

8. Sklyarenko, Yu. I., 2018. Vliyanie intensivnosti razvitiya telochek na ikh dal'neyshie khozyaystvenno-poleznye priznaki [Influence of intensity development of calfs on their further economically useful features]. Nauchno-tekhnicheskiy byulleten' Instituta zhivotnovodstva Natsional'noy akademii agrarnykh nauk Ukrainy, issue 119, pp. 134-141.

9. Khmelnychyi, L. M. 2012. Otsinka rostu ta rozvytku telyts' ukrayins'koyi chervono-ryaboyi mo-lochnoyi porody za vykorystannya vahovykh ta liniynykh parametriv - Estimation of the growth and develop-ment of heifers Ukrainian Red-and-White Dairy breed using weighing and linear parameters. Visnyk Sums'koho NAU. Seriya Tvarynnytstvo - Bulletin of Sumy National Agrarian University, series of Animal Husbandry. issue 12 (21), pp.18-21.

10. Khmelnychyi L. M. and Loboda V. P., 2014 Kharakterystyka remontnykh telyts' ukrayinskoyi chervono-ryaboyi molochnoyi porody za rozvytkom zhyvoyi masy - Characteristics of repair heifers of Ukrainian red-spotted dairy breed for development of living mass. Visnyk Sums'koho NAU. Seriya Tvarynnytstvo - Bulletin of Sumy National Agrarian University, series of Animal Husbandry. issue $2 / 2$ (25), pp. 3-6.

11. Khmelnychyi L. M., 2005. Otsinka ekster"yeru tvaryn v systemi selektsiyi velykoyi rohatoyi khudoby: dys. doktora sil's'kohospodars'kykh nauk : 06.02.01 Khmel'nychyy Leontiy Mykhaylovych. s. Chubyns'ke - Estimation of the exterior animals in the selection system of cattle: dissertation of the Doctor of Agricultural Sciences: 06.02.01 Khmelnychyi Leontyi Mykhailovych. v. Chubyns'ke, 430.

12. Chernyavskaya, T.A., Sklyarenko, Yu.I. and Ivankova, I.P., 2017. Vliyanie intensivnosti razvitiya remontnykh telok ukrainskoy buroy molochnoy porody na produktivnost' korov-pervotelok [The influence of the intensity of development of repair heifers of Ukrainian brown milk breed on the productivity of first-calf cows. Integration of science and practice for development of agroindustrial complex]. Sbornik statey Vserossiyskoy nauchnoy konferentsii, pp. 113-119.

\section{Rubtsov Ihor Alexandrovich, PhD of Agricultural Sciences, Docent, Sumy National Agrarian University (Sumy, Ukraine) Comparative assessment of heifers of Ukrainian Black-and-White and Red-and-White dairy breeds by growth, measurements and live weight gain in Chernihiv region}

The state of breeding repair young cattle of dairy productivity has always been of interest to livestock specialists. This was primarily due to the fact that under optimal conditions, the phenotype of animals was formed, which approached the genetic potential of milk productivity. In today's market relations, this is of great importance for obtaining high quality products with minimal costs and lower costs. Therefore, the aim of the article was to compare the growth characteristics of animals of the two main breeds bred in Ukraine, as well as to establish the features of the formation of the exterior and milk type in repair heifers at different ages. The research was conducted in the conditions of PLAE (private leased agricultural enterprise) "Hliborob" of Ichnia district of Chernihiv region. A comparative analysis of the state of growing repair young stock of Ukrainian black-and-white and red-and-white dairy breeds was carried out by analyzing the live weight from birth to 18 months, and taking basic measurements with subsequent calculation of body structure indices. No significant difference between animals of both breeds in terms of growth was found. So at birth 
and at 3 months there was no difference at all. At 6 months, she weighed $3.1 \mathrm{~kg}$ in favor of heifers of the Ukrainian red-and-white dairy breed. At the age of 6 months, we observed some excess of the animals of the Ukrainian black-and-white dairy breed by 3.3 $\mathrm{kg}$. This excess was observed in the future, and already at 18 months was $8.1 \mathrm{~kg}$, but as in previous periods, it was incredible. Daily gains for this period ranged from birth to 3 months 779.4 and $778.3 \mathrm{~g}$, respectively, for Ukrainian black-and-white milk and Ukrainian red-and-white milk, from 3 to 6 months 818.6 and $853.1 \mathrm{~g}$, from birth to 6 months 799.0 and $815.7 \mathrm{~g}$, from 6 to 12 months 807.3 and $771.9 \mathrm{~g}$, from birth to 9,12 and up to 18 months 808.8 and 801.1 and 792.1 and $782.9 \mathrm{~g}$ and 751.9 and $736.9 \mathrm{~g}$. In all age periods, no significant difference between breeds was found. The recurrence rate of live weight at birth with live weight at 3 months in Ukrainian black-and-white dairy animals was +0.138 , at 6 months +0.134 , at 12 months +0.104 , at 18 months +0.105 . In the first two periods it was probable ( $P>0.95)$, then in recent periods it is improbable. Indicators of measurements and body structure indices also indicated that animals of both breeds are well developed, have a clear bias towards the formation of dairy animals.

Key words: Ukrainian Black-and-White dairy, Ukrainian Red-and-White dairy, measurements, indices, conformation.

Дата надходження до редакиії: 13.02.2020 p. 